\title{
Ultrastructural integrity of mouse testicular cells separated by velocity sedimentation
}

\author{
W. J. Barcellona and M. L. Meistrich
}

Department of Biology, Texas Christian University, Fort Worth, Texas 76129 , and Section of Experimental Radiotherapy, The University of Texas System Cancer Center, M.D. Anderson Hospital and

Tumor Institute, Houston, Texas 77030 , U.S.A.

\begin{abstract}
Summary. Mouse testicular cells were examined ultrastructurally to determine whether the cells are damaged during the preparation of single-cell suspensions or during cell separation. The testicular cells were dissociated from seminiferous tubules by trypsinization and were fixed immediately; fixed after being held in suspension for $4 \mathrm{~h}$ at $4^{\circ} \mathrm{C}$; or fixed after being separated into enriched fractions by sedimentation velocity either at unit gravity or by centrifugal elutriation. In general, the ultrastructural integrity of the cells, compared with that of corresponding testicular cells fixed in situ, was maintained during the dissociation and separation procedures. Ultrastructural abnormalities were most frequently produced in Sertoli cells and were occasionally observed in the acrosomes and nuclei of round spermatids. The cytoplasmic matrix of the midpiece of mature elongated spermatids or spermatozoa and the acrosomes of these cells were often disrupted. It is suggested that the dissociation procedures were responsible for most of the observed alterations of ultrastructural integrity.
\end{abstract}

\section{Introduction}

Methods have recently been developed for the separation of testicular cells into fractions enriched in specific cell types; for example, fractions containing pachytene spermatocytes, round spermatids, and elongated spermatids in over $80 \%$ purity have been obtained by velocity sedimentation (Meistrich, 1976). Such fractions are proving to be extremely useful for elucidating the biochemical changes which occur in the various cell types during spermatogenesis (Vernon, Go \& Fritz, 1971; Lee \& Dixon, 1973; Letts, Meistrich, Bruce \& Schachter, 1974; Platz, Grimes, Meistrich \& Hnilica, 1975; Grimes, Platz, Meistrich \& Hnilica, 1975; Sanborn, Steinberger, Meistrich \& Steinberger, 1975). However, the integrity of testicular cells in single-cell suspensions has been questioned, particularly since germinal cells are interconnected by cytoplasmic bridges (Dym \& Fawcett, 1971) which must be broken during the preparation of suspensions. In addition, degeneration could occur during the time required for separation, or damage could be produced by the stresses involved in separation procedures.

Other studies have already shown that most cell membranes are functionally intact (Meistrich, 1972), macromolecular synthesis continues relatively normally (Meistrich, 1972) and certain biochemical properties of the cells are unaltered (Letts et al.,1974; Platz et al., 1975). In the present study, we have analysed the integrity of isolated and separated testicular cells by electron microscopy which is a sensitive method for detecting cell degeneration.

\section{Materials and Methods}

Animals. The male mice used were of the inbred C3Hf/Bu strain, maintained in a specific pathogenfree colony, and were 9-12 weeks of age and with an average body weight of $30 \mathrm{~g}$. Testicular tissue was used immediately after killing the animals by cervical dislocation. 


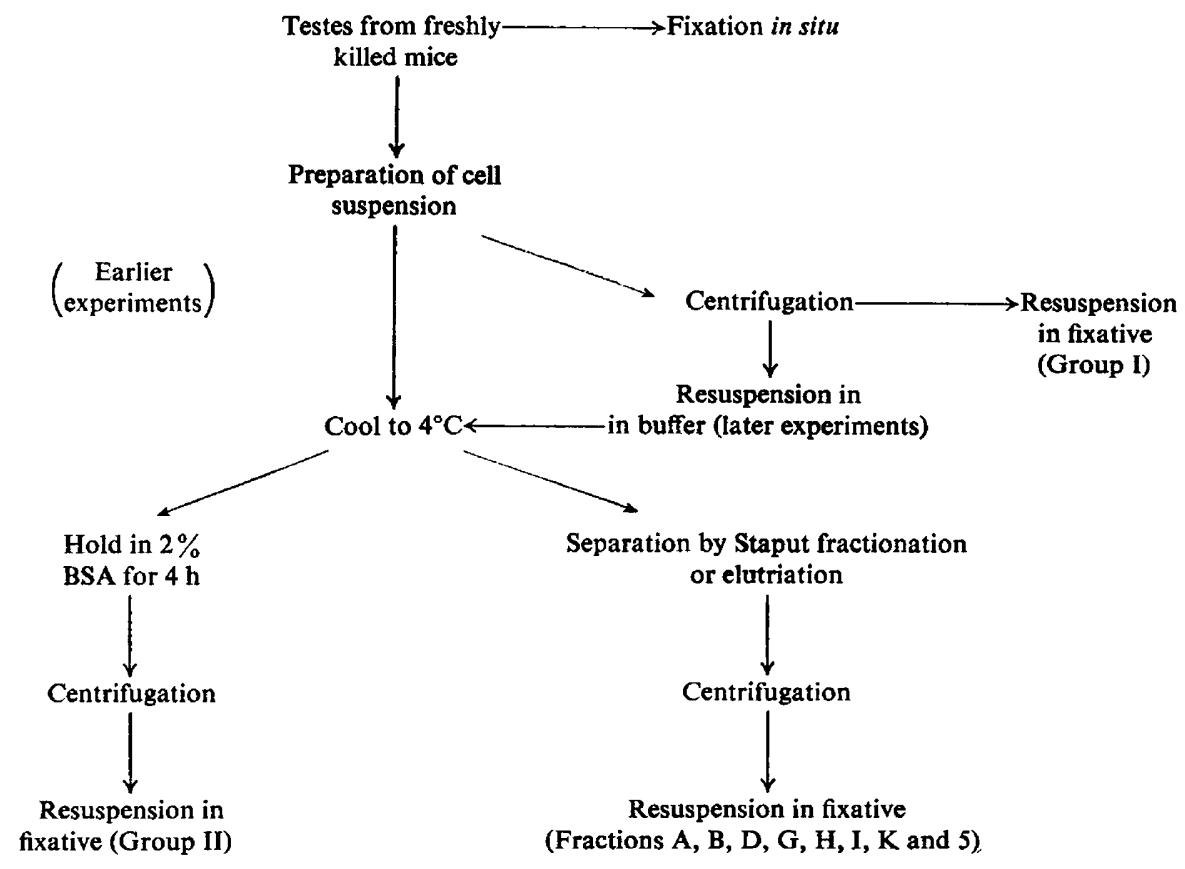

Text-fig. 1. Flow diagram for separation of testicular cells and fixation for electron microscopy.

Preparation of cell suspensions. These were prepared by the trypsin method employing crude trypsin and DNase in phosphate-buffered saline (PBS) containing $\mathbf{0 . 1} \%$ glucose as described previously (Meistrich, 1972, 1976). In the early Staput-separation experiments, cells were used without centrifugation, but in later experiments the cells were first centrifuged at $500 \mathrm{~g}$ for 15 min and resuspended in PBS containing $0.02 \mathrm{mg}$ crude DNase $/ \mathrm{ml}$. For elutriator-separation experiments, the cells were centrifuged and resuspended in PBS containing a trypsin inhibitor (Code SI: Worthington Biochemical Corporation, Freehold, New Jersey) and the dipotassium salt of 2-naphthol-6,8disulphonic acid (Eastman Chemicals, Rochester, New York) as described by Platz et al. (1975). Cells were fixed immediately after preparation (Group I), were held in $2 \% \mathrm{BSA}$ at $4^{\circ} \mathrm{C}$ for $4 \mathrm{~h}$ and then fixed (Group II), or were separated as described below and then fixed (see Text-fig. 1).

\section{Separation of testicular cells}

Staput method. The Staput technique of velocity sedimentation at unit gravity (Miller \& Phillips, 1969; Lam, Furrer \& Bruce, 1970) was used with a 1-4\% non-linear gradient of bovine serum albumin (BSA) (Platz et al., 1975). Cells were allowed to sediment for $4 \mathrm{~h}$ before unloading the chamber. Several fractions were pooled and concentrated for each sample for electron microscopy, and the pooled fractions were designated $\mathrm{A}, \mathrm{B}, \mathrm{D}, \mathrm{G}, \mathrm{H}, \mathrm{I}$ and $\mathrm{K}$ so that the cellular composition would most closely conform to that of the fractions obtained by Meistrich et al. (1973).

Centrifugal elutriation. Separation by centrifugal elutriation in the JE-6 Elutriator Rotor (Beckman Instruments, Palo Alto, California) was essentially as described previously (Grabske, Lake, Gledhill \& Meistrich, 1975) except that $5 \mathrm{~mm}$-naphthol disulphonic acid was included in the buffer solution. Also, before elutriation, cell suspensions were filtered through $25 \mu \mathrm{m}$ nylon mesh to remove any large clumps of cells or other debris. The range of sedimentation rates included in each fraction was wider than in the previous study by Grabske et al. (1975), thus accounting for lower cell purity. The fraction containing cells with sedimentation rates between 4.5 and $10.4 \mathrm{~mm} / \mathrm{h}$ was designated Fraction 5 because it was similar to the fraction of that number obtained by Grabske et al. (1975). 
Differential counts of cells in fractions. Smears of the cells in each fraction were prepared and stained with periodic acid-Schiff-haematoxylin as described by Meistrich et al. (1973), and at least 250 cells were counted in each fraction.

\section{Electron microscopy}

Testicular cells in suspension. Samples from unfractionated cell suspensions and from Staput or Elutriator fractions were fixed in $3 \%$ glutaraldehyde in Millonig's phosphate buffer, $\mathrm{pH} 7 \cdot 4$ (Millonig, 1961). Samples were then washed twice in phosphate buffer, post-fixed for $1 \mathrm{~h}$ in phosphate-buffered $1 \%$ osmium tetroxide, washed in distilled water and rapidly dehydrated by centrifugation and resuspension through a graded series of ethanol. Samples were then centrifuged and resuspended for infiltration, centrifuged into a pellet and embedded in a low viscosity medium (Spurr, 1969). Thick sections $(2 \mu \mathrm{m})$ were cut with glass knives, stained with Azure II-methylene blue (Richardson, Jarett \& Finke, 1960) and observed under the light microscope. Blocks were further trimmed to specified areas and thin sections were cut on a Porter-Blum MT-2 ultramicrotome with a Dupont diamond knife and stained on 200-mesh copper grids with saturated uranyl acetate in $50 \%$ ethanol and lead citrate (Reynolds, 1963) according to the method of Mollenhauer (1974). All grids were observed in a Philips EM 300 electron microscope at an accelerating voltage of $60 \mathrm{Kv}$.

Testicular cells in situ. Testes were prepared by removing the tunica albuginea, dicing with a sharp scalpel in phosphate-buffered $3 \%$ glutaraldehyde, and processing for electron microscopy as described above. The stages of spermatogenesis defined by Oakberg (1956) were identified in thick sections of tissue blocks. Blocks were then trimmed to particular areas of seminiferous tubules that contained specific types of germinal cells, and thin sections were stained and examined.

\section{Results and Discussion}

\section{Sertoli cells}

In a Sertoli cell in situ (Pl. 1, Fig. 1), vacuolization of the endoplasmic reticulum membranes was evident, discrete Golgi complexes were located in the supranuclear region, and lipid droplets, lysosomes and mitochondria were present in the cytoplasmic matrix. Many Sertoli cells in Groups I and II showed cytoplasmic damage and degradation which was apparent even in the light microscope.

\section{EXPLANATION OF PLATES}

\section{PLATE 1}

Fig. 1. Sertoli cell fixed in situ within a seminiferous tubule. Arrows indicate vacuolated endoplasmic reticulum. $\times 5,700$.

Fig. 2. Isolated Sertoli cell recovered from Staput fraction A. Arrow indicates cisternae of endoplasmic reticulum and cytoplasmic vacuoles (CV). Sertoli cells composed $3 \%$ of the cells in the fraction. $\times 4,150$.

Fig. 3. Spermatogonium fixed in situ within a stage VI seminiferous tubule. $\times 8,525$.

Fig. 4. Isolated spermatogonium recovered from elutriator fraction 5 . Spermatogonial cells composed $2 \%$ of the fraction. $\times 7,300$.

\section{PLATE 2}

Fig. 5. Leptotene spermatocyte fixed in situ within a stage $X$ seminiferous tubule. Arrow indicates unpaired axial chromosomal filaments. $\times 6,700$.

Fig. 6. Isolated leptotene spermatocyte recovered from Staput fraction G. Arrow indicates unpaired axial chromosomal filaments. Young primary spermatocytes, leptotene through early pachytene cells, composed $2 \%$ of the fraction. $\times 7,160$.

Fig. 7. Mid-pachytene spermatocyte fixed in situ within a stage V seminiferous tubule. SC, synaptonemal couples. $\times 4,580$.

Fig. 8. Isolated mid-pachytene spermatocyte recovered from Staput fraction B-1. Arrows indicate concavely orientated endoplasmic reticulum, and SC denotes synaptonemal complex. Pachytene spermatocytes composed $65 \%$ of the fraction. $\times 4,770$. 


\section{PLATE 3}

Fig. 9. Diplotene spermatocyte fixed in situ within a stage XII seminiferous tubule. $\times 5,200$.

Fig. 10. Isolated diplotene spermatocyte recovered from Staput fraction B-2. Diplotene cells were included with pachytene spermatocytes for determination of the $\%$ composition of the fraction which was $69 \%$. $\times 4,535$.

Fig. 11. Isolated multinucleated spermatid recovered from Staput fraction A. CB, chromatid body; CV, cytoplasmic vacuole. Multinucleated spermatids composed $15 \%$ of the fraction. $\times 4,085$.

Fig. 12. Isolated binucleate spermatid recovered from elutriator fraction 5. CB, chromatid body; CV, cytoplasmic vacuole. Binucleate spermatids composed $6 \%$ of the fraction. $\times 5,800$.

Fig. 13. A step 2 spermatid fixed in sit $u$ within a stage II seminiferous tubule. $\times 6,425$.

Fig. 14. Isolated step 2 spermatid with two acrosomic vesicles recovered from Staput fraction $H$. Spermatids of steps $1-8$ composed $5 \%$ of the fraction. $\times 6,145$.

\section{PLATE 4}

Fig. 15. A step 5 spermatid fixed in situ within a stage V seminiferous tubule. $\times 8,160$.

Fig. 16. Isolated step 5 spermatid recovered from Staput fraction G. Note the electron-lucent 'nuclear vacuole' (NV). Spermatids of steps $1-8$ composed $4 \%$ of the fraction. $\times 8,160$.

Fig. 17. A step 9 spermatid fixed in situ within a stage IX seminiferous tubule. CB, chromatid body. $\times 6,155$.

Fig. 18. Isolated step 9 spermatid recovered from Staput fraction G. CB, chromatid body displaced towards the anterior part of the cell. Step 9-10 spermatids composed $2 \%$ of the fraction. Arrows indicate the manchette. $\times 6,885$.

Fig. 19. Isolated step 9 spermatid with a vacuolated acrosome (arrow) recovered from Staput fraction $\mathrm{G}$. Step $9-10$ spermatids composed $2 \%$ of the fraction. $\times 14,400$.

\section{PLATE 5}

Fig. 20. A step 11 spermatid fixed in situ within a stage XI seminiferous tubule. $\times 6,110$.

Fig. 21. Isolated step 11 spermatid recovered from Staput fraction G. Arrows indicate swollen endoplasmic reticulum. Step $11-13$ spermatids composed $10 \%$ of the fraction. $\times 6,975$.

Fig. 22. Step 13 spermatids fixed in situ within a stage I seminiferous tubule. Arrow indicates annulate lamellae. $\times 4,150$.

Fig. 23. Isolated step 13 spermatid recovered from an initial whole cell suspension held in Staput medium for $4 \mathrm{~h}$ at $4^{\circ} \mathrm{C}$ (Group II). $\times 9,065$.

Fig. 24. Step 15 spermatids fixed in situ within a stage IV seminiferous tubule. $\times 4,880$.

Fig. 25. Isolated elongated spermatid recovered from Staput fraction $\mathrm{K}$. This spermatid is of the same approximate stage of development as the one in Fig. 24. Note the cytoplasmic debris (CD). Step 11-16 spermatids with a tail composed $13 \%$ of the fraction. $\times 8,935$.

\section{PLATE 6}

Fig. 26. Isolated elongated spermatid heads or sperm heads recovered from Staput fraction K. Step 11-16 sperm heads composed $14 \%$ of the fraction. $\times 7,750$.

Fig. 27. Isolated elongated spermatid or spermatozoon recovered from Staput fraction K. Note the isolated mitochondria (arrow) and the lack of cytoplasmic matrix associated with the midpiece. Step 11-16 spermatids with tails composed $13 \%$ of the fraction. $\times 5,470$.

Fig. 28. Residual body fixed in situ within a stage IX seminiferous tubule. $\times 14,245$.

Fig. 29. Isolated residual body recovered from Staput fraction I. Residual bodies composed $18 \%$ of the fraction. $\times 14,170$.

Fig. 30. Isolated cytoplasmic fragment recovered from Staput fraction $H$. Note the annulate lamellae (AL). Cytoplasmic fragments composed $66 \%$ of the fraction. $\times 9,915$. 

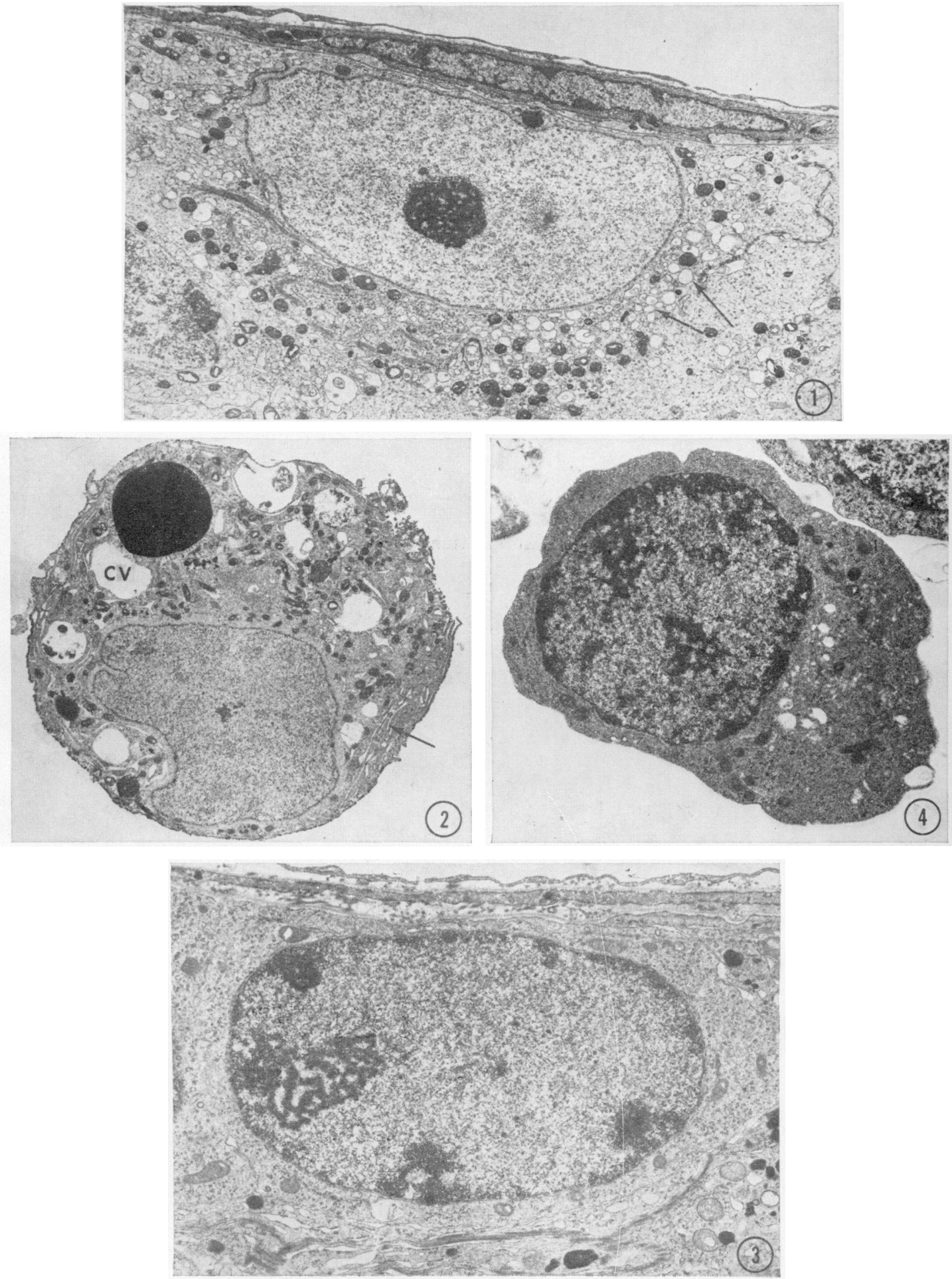
PLATE 2
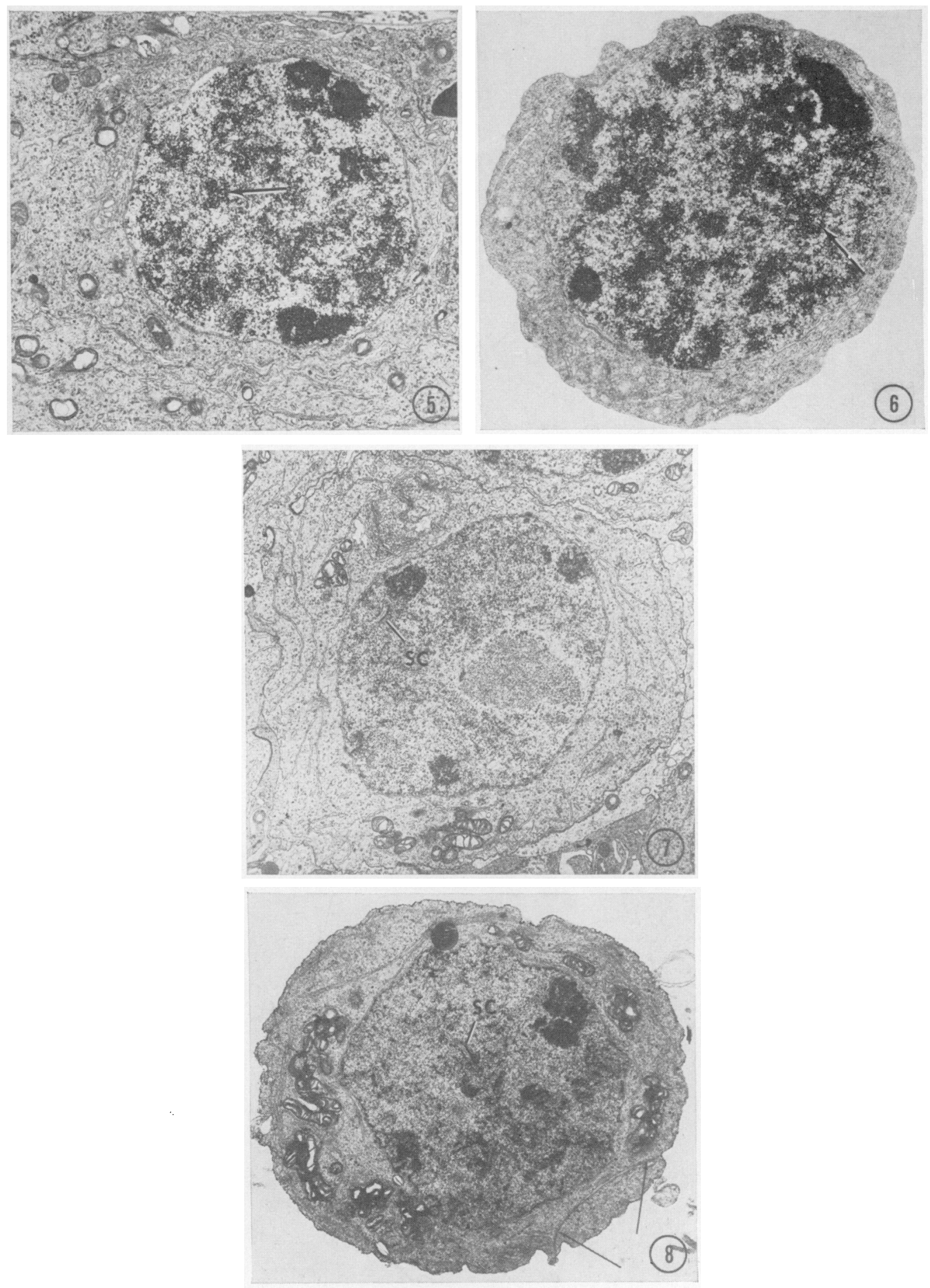
PLATE 3

PLATE 4
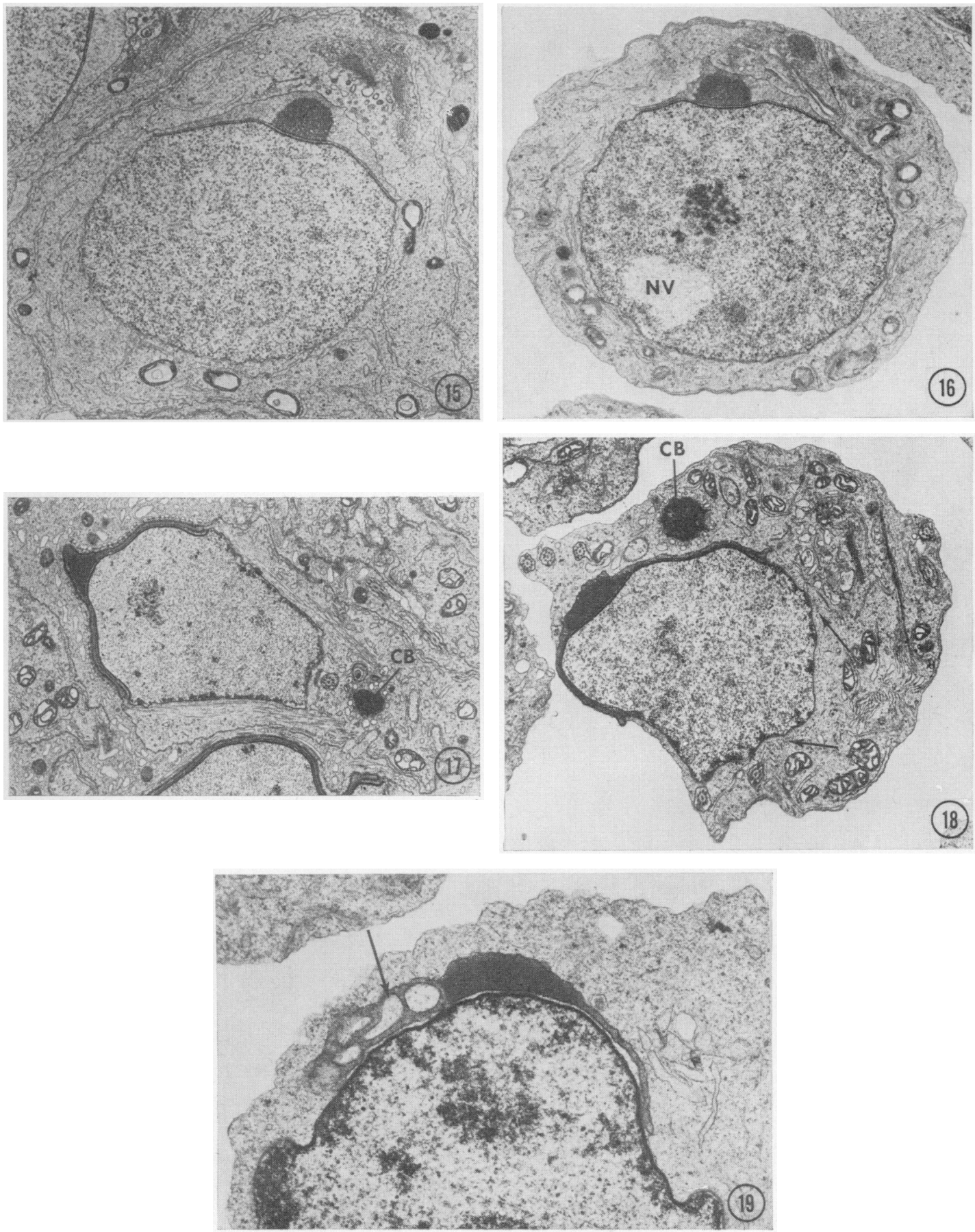
PLATE 5
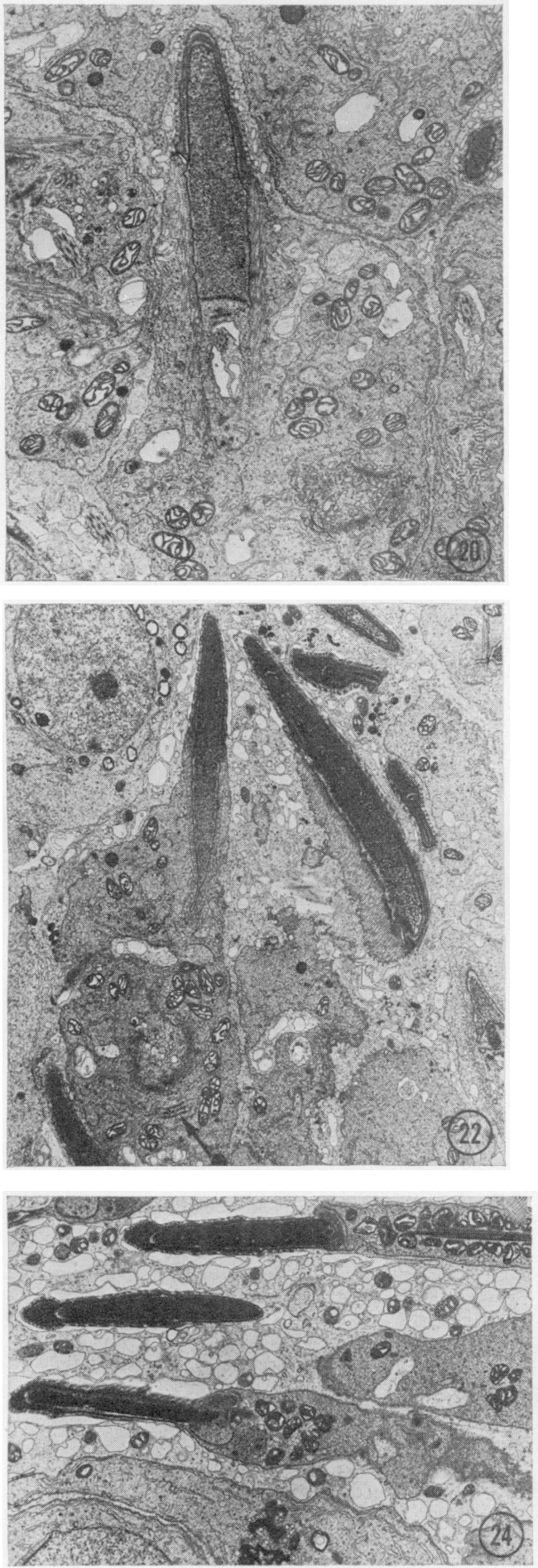

PLATE 6

In a relatively intact Sertoli cell recovered from Staput Fraction A (Pl. 1, Fig. 2), the endoplasmic reticulum membranes were in the form of cisternae, and a very large lipid droplet and large vacuoles (some with partly degraded internal contents) were present in the cytoplasm.

It is clear that Sertoli cells are adversely affected by the dissociation procedure because many of these cells in the initial control suspensions appeared necrotic and degenerate. The cells observed from Staput Fraction A showed more nearly normal morphology, perhaps because they had been selected on the basis of their higher sedimentation rates (Meistrich, 1972). The large cytoplasmic vacuoles in these cells may have been produced by the dissociation procedure or, judging from their contents, may be secondary lysosomes. The endoplasmic reticulum in some mouse Sertoli cells is normally vacuolated. However, in others it is non-vacuolated. A difference in physiological state between these two types of Sertoli cells has been suggested by Kierszenbaum (1974). It is possible that the cells illustrated in Pl. 1, Figs 1 and 2 may similarly represent different physiological states. Nevertheless, some of the cytoplasmic vacuoles in the isolated Sertoli cell were so large that they are almost certainly caused by cell dissociation.

\section{Spermatogonia}

The spermatogonium shown in Pl. 1, Fig. 4 was recovered from elutriator Fraction 5 and was tentatively identified as a Type B spermatogonium, although it contained cytoplasmic vacuoles of various sizes which were not present in the tissue control (Pl. 1, Fig. 3). Similar vacuoles, however, were found in isolated spermatogonia from Staput Fraction $G$ as well as in spermatogonia from Group I and Group II suspensions. No other significant differences were observed between separated and in-situ spermatogonia.

\section{Primary spermatocytes}

Comparison of leptotene cells from a stage X seminiferous tubule (PI. 2, Fig. 5) and those from Staput Fraction G (P1. 2, Fig. 6) showed that chromosomes with unpaired axial filaments were present in the nucleus which was surrounded by a thin rim of cytoplasm containing clusters of polyribosomal units. The ultrastructural integrity of the fractionated leptotene spermatocytes was the same as that of the tissue controls.

In the tissue control, mid-pachytene cells from a stage $\mathrm{V}$ seminiferous tubule showed normal autosomal synaptonemal complexes, mitochondria which were normally vacuolated and clumped around a granular cytoplasmic substance and endoplasmic reticular membranes which were generally in the form of long cisternae orientated around the nucleus (Pl. 2, Fig. 7). Isolated cells from Groups I and II as well as from Staput Fraction B in one experiment (denoted as Staput Fraction B-2) were ultrastructurally virtually identical to the tissue controls. However, in one experiment, some midand late pachytene cells from Staput Fraction B (denoted as Staput Fraction B-1) displayed abnormalities in the ultrastructure of some cellular membranes: some cells possessed granular endoplasmic reticular membranes which displayed a concave orientation with respect to the nucleus (PI. 2, Fig. 8) and some exhibited abnormal separation of short segments of the double membranes composing the endoplasmic reticulum and nuclear envelope.

The ultrastructure of a diplotene cell from a stage XII seminiferous tubule (Pl. 3, Fig. 9) and a cell from Staput Fraction B-2 (Pl. 3, Fig. 10) was comparable.

In general, primary spermatocytes do not appear to be adversely affected by dissociation from the seminiferous epithelium nor by subsequent separation in BSA by the Staput method. In one experiment, however, in which the cells were not centrifuged before the fractionation, some mid- and late pachytene spermatocytes from Staput Fraction B displayed abnormalities of the membranes of the endoplasmic reticulum and nuclear envelope. It is possible that the abnormalities represent an artefact of fixation of this particular sample, but we cannot exclude the possibility that spermatocytes may be damaged by dissociation techniques used in this experiment. 


\section{Spermatids}

Multinucleated cells were produced during the dissociation of cells from seminiferous tubules. Multinucleated round spermatids appeared in the Staput (Pl. 3, Fig. 11) and elutriator (Pl. 3, Fig. 12) fractions. Cytoplasmic vacuoles adjacent to the plasma membrane also appeared in a similar location in multinucleated spermatids from unfractionated control suspensions (Groups I and II), but they were not found in round spermatids or in the tissue control.

Uninucleate spermatids in various stages of development were also examined. Step 2 spermatids displayed normal ultrastructure (Pl. 3, Figs 13 and 14) with the exception of occasional cytoplasmic vacuoles adjacent to the plasma membrane as described above. The mitochondria were typically vacuolated, sometimes containing a membranous vesicle similar to those shown by Dooher \& Bennett (1973).

Unlike that in the tissue control (Pl. 4, Fig. 15), isolated round spermatids occasionally contained 'nuclear vacuoles' of spherical shape, reduced granularity and reduced electron density (P1. 4, Fig. 16). These vacuoles were observed in close association with dense bodies and nucleolar-like bodies in $15-20 \%$ of early to mid-spermatids which were fractionated by the Staput method. These regions of low electron density were also found in the Group II suspensions but not in the Group I suspensions or in the tissue controls. This result indicates that the nuclear damage was due to the storage of the cells rather than the preparation.

The morphology of step 9 spermatids from Staput Fraction G (PI. 4, Fig. 18) was similar to that of tissue control spermatids (P1. 4, Fig. 17), except for rearrangement of intracellular structures which occurs as the cells round up, e.g. displacement of the chromatid body. Manchette microtubules were present in both cells. Vacuolated acrosomes (Pl. 4, Fig. 19) were observed in approximately $20 \%$ of the early to mid-spermatids from the Staput fractions and the control suspension (Groups I and II) but were not seen in tissue control spermatids. These results are in agreement with those of Loir \& Lanneau (1974) who studied ram spermatids. Romrell, Bellvé \& Fawcett (1976) did not report either of the above-mentioned spermatid abnormalities: the only difference in their methods which could account for such better preservation was the use of a more enriched buffer solution in the preparation of the cell suspensions and in cell separation.

Step 11 spermatids in the control tissue (Pl. 5, Fig. 20) and Staput Fraction G (Pl. 5, Fig. 21) were very similar and identical to similar spermatids of the same step of maturation from the Group I and II suspensions. In the isolated cells, the cisternae of the endoplasmic reticulum were sometimes more swollen than in the tissue control cells.

The ultrastructure of step 13 spermatids in the isolated cell preparations (P1. 5, Fig. 23) was similar to that in the control tissue (Pl. 5, Fig. 22), except that the nucleus was displaced to the periphery of the cytoplasm, which had become rounded.

Beginning at step 8 of spermiogenesis, the nucleus and acrosome of the spermatid are invested by the Sertoli cell while the bulk of the cytoplasm is displaced caudally. Structures within the Sertoli cell may influence the overall distribution of spermatid cytoplasm in later spermatogenic stages (Fawcett, 1975; Dooher \& Bennett, 1973). The roundness of the isolated cells probably results from the disruption of the Sertoli cell-spermatid relationship by the cell-dissociation procedures, thereby removing any influence that Sertoli cells might exert on the spatial distribution of cytoplasm in elongating spermatids.

Some isolated spermatids (step 15) displayed normal nuclear, acrosomal and midpiece ultrastructure (Pl. 5, Fig. 25) compared with that of spermatiđs fixed in situ (Pl. 5, Fig. 24). The cellular debris found adjacent to some spermatids may have been caused by damage to cells during concentration and pelleting or have been present in the initial suspension and sedimented with the late spermatids, as were small cytoplasmic fragments (Pl. 5, Fig. 25 and Pl. 6, Figs 26 and 27). Other elongated spermatids from Fraction $\mathbf{K}$ showed various forms of ultrastructural damage, e.g. a partly detached or absent acrosome (Pl. 6, Fig. 26), lack of cytoplasmic matrix in the midpiece (P1. 6, Fig. 27), and the appearance of isolated mitochondria (Pl. 6, Fig. 27). Intact and disrupted elongated spermatids or spermatozoa were also found in unfractionated whole-cell suspensions (Groups I and II). 


\section{Residual bodies and cytoplasmic fragments}

Cytoplasmic fragments were commonly observed in Group I and Group II cell suspensions as well as in Staput fractions containing slowly sedimenting cells. Some displayed the morphological characteristics typical of residual bodies (Pl. 6, Figs 28 and 29), which are detached from mature spermatids at Stages VIII and IX, but most resembled that shown in Pl. 6, Fig. 30. Such fragments contained mitochondria and other organelles with an ultrastructure very similar to that of organelles found in the cytoplasm of step 9-13 spermatids (Pl. 4, Figs 17 and 18; Pl. 5, Figs 20, 21, 22 and 23). Annulate lamellae were present in fractionated cytoplasmic fragments and in the cytoplasm of some early elongated spermatids (P1. 5, Fig. 22). Dense osmiophilic bodies were also observed (PI. 5, Figs 20, 21, 22 and 23; Pl. 6, Fig. 30). The cytoplasmic fragments present in cell suspensions are probably generated from elongating and elongated spermatids by the stresses produced during the cell-dissociation steps (Meistrich, 1973), as these fragments (Pl. 6, Fig. 30) show a great deal of ultrastructural similarity to the cytoplasm which undergoes caudal displacement in maturing spermatids.

\section{Conclusions}

Waymouth (1974) suggested that cells are most susceptible to stresses encountered in the initial celldissociation procedures, and our present observations support this proposal. When compared to tissue controls, nearly all of the ultrastructural abnormalities found in cells in the Staput or elutriator fractions were also observed in initial control suspensions. It would be reasonable to conclude that the Staput or elutriator methods of cell separation and the media utilized therein did not affect the ultrastructural integrity of isolated mouse testicular cells but that the mechanico-chemical celldissociation method produced most of the ultrastructural alterations which were observed.

Although the methods for preparation of cell suspensions we have been employing (PBS-glucose with trypsin and DNase) produce some damage at the ultrastructural level, the ultrastructural integrity of most of the cells is unaffected and is comparable to that of cells prepared by Romrell et al. (1976) in enriched Krebs-Ringer bicarbonate medium with the use of collagenase, trypsin and DNase and more gentle mechanical handling. Cell integrity is probably adequate for use of the separated cell suspensions for biochemical studies of these cells and their organelles. The two cell types most adversely affected are the Sertoli cells and late elongated spermatids. Yet, despite the ultrastructural abnormalities, the nuclear proteins of these late spermatids show no evidence of degradation (Platz et al., 1975).

We thank Dale W. Koehler, Patricia K. Trostle and Betty O. Reid for expert technical assistance. This study was supported in part by a grant from the Texas Christian University Research Foundation, NIH grants CA-06294, CA-17364, and a National Science Foundation grant PCM 76-08836.

\section{References}

Dooher, G.B. \& Bennetr, D. (1973) Fine structural observations on the development of the sperm head in the mouse. Am. J. Anat. 136, 339-362.

DYM, M. \& FAwCETT, D.W. (1971) Further observations on the numbers of spermatogonia, spermatocytes and spermatids connected by intercellular bridges in the mammalian testis. Biol. Reprod. 4, 195-215.

FAWCETT, D.W. (1975) The ultrastructure and functions of the Sertoli cell. In Handbook of Physiology; Vol. V, Male Reproductive System, Section 7: Endocrinology, pp. 21-55. Eds D.W. Hamilton and R.O. Greep. Am. Physiol. Soc., Washington, D.C.

GrabsKe, R.J., LAKE, S., Gledhill, B.L. \& MeISTRICH, M.L. (1975) Centrifugal elutriation: separation of spermatogenic cells on the basis of sedimentation velocity. J. cell. Physiol. 86, 177-190.

Grimes, S.R., Jr, Platz, R.D., Meistrich, M.L. \& HNiliCA, L.S. (1975) Partial characterization of a new basic nuclear protein from rat testis elongated spermatids. Biochem. Biophys. Res. Commun. 67, 182-189.

Kierszenbaum, A.L. (1974) RNA synthetic activities of Sertoli cells in the mouse testis. Biol. Reprod. 11, 365376.

LAM, D.M.K., Furrer, R. \& BruCE, W.R. (1970) The separation, physical characterization, and differentiation kinetics of spermatogonial cells of the mouse. Proc, natn. Acad. Sci. U.S.A. 65, 192-199. 
LEE, I.P. \& DIXON, R.L. (1973) Effects of cadmium on spermatogenesis studied by velocity sedimentation cell separation and serial mating. J. Pharmac. exp. Therap. 187, 641-652.

Letts, P.J., Meistrich, M.L., Bruce, W.R. \& SChachTER, H. (1974) Glycoprotein glycosyltransferase levels during spermatogenesis in the mouse. Biochim. biophys. Acta 343, 192-207.

LoIR, M. \& LANNEAU, M. (1974) Separation of ram spermatids by sedimentation at unit gravity. Expl Cell Res. 83, 319-327.

MeISTRICH, M.L. (1972) Separation of mouse spermatogenic cells by velocity sedimentation. $J$. cell. Physiol. 80, 299-312.

MeISTRICH, M.L. (1976) Separation of rodent spermatogenic cells. In Methods in Cell Biology, pp. 15-54. Ed. D.M. Prescott. Academic Press, New York.

Meistrich, M.L., Bruce, W.R. \& Clermont, Y. (1973) Cellular composition of fractions of mouse testis cells following velocity sedimentation separation. Expl Cell Res. 79, 213-227.

Miller, R.G. \& Phillips, R.A. (1969) Separation of cells by velocity sedimentation. $J$. cell. Physiol. 73, 191202.

Millonig, G. (1961) Advantages of a phosphate buffer for $\mathrm{OsO}_{4}$ solutions in fixation. J. appl. Physics 32, 1637.

Mollenhauer, H.H. (1974) Poststaining sections for electron microscopy. Stain Technol. 49, 305-308.

OAKBerg, E.F. (1956) A description of spermatogenesis in the mouse and its use in analysis of the cycle of the seminiferous epithelium and germ cell renewal, $\mathrm{Am}$. J. Anat. 99, 381-413.

Platz, R.D., Grimes, S.R., Meistruch, M.L. \& Hnilica, L.S. (1975) Changes in nuclear proteins of rat testis cells separated by velocity sedimentation. $J$. biol. Chem. 250, 5791-5800.

REYNOLDS, E.S. (1963) The use of lead citrate at high pH as an electron-opaque stain in electron microscopy. J. Cell Biol. 17, 208-212.

Richardson, K.C., JaRetT, L. \& Finke, E. (1960) Embedding in epoxy resins for ultrathin sectioning in electron microscopy. Stain Technol. 35, 313-323.

RomRell, L.J., BellvE, A.R. \& FAWCETT, D.W. (1976) Separation of mouse spermatogenic cells by sedimentation velocity: a morphological characterization. Devl Biol. 49, 119-131.

Sanborn B.M., Steinberger, A., Meistrich, M.L. \& Steinberger, E. (1975) Androgen binding sites in testis cell fractions as measured by a nuclear exchange assay. J. Steroid Biochem. 6, 1459-1465.

SpURR, A.R. (1969) A low-viscosity epoxy resin embedding medium for electron microscopy. J. Ultrastruct. Res. 26, 31-43.

Vernon, R.G., Go, V.L.W. \& Fritz, I.B. (1971) Studies on spermatogenesis in rats. II. Evidence that carnitine acetyltransferase is a marker enzyme for the investigation of germ cell differentiation. Can. J. Biochem. 49, 761-767.

WAYMouTh, C. (1974) To disaggregate or not to disaggregate. Injury and cell disaggregation, transient or permanent? In Vitro 10, 97-111.

Received 12 August 1976 